DOI: 10.25557/0031-2991.2020.02.46-53

С Маклакова И.Ю., Гребнев Д.Ю, 2020

уДК 616-092

Маклакова И.Ю. ${ }^{1,2}$, Гребнев Д.Ю., ${ }^{1,2}$

Коррекция морфофункционального состояния печени при остром гепатите с помощью стволовых клеток

\author{
ФГБОУ ВО Уральский государственный медицинский университет Минздрава России, \\ 620028, г. Екатеринбург, ул. Репина, д. 3; \\ 2ГАУЗ СО «Институт медицинских клеточных технологий», \\ 620026 г. Екатеринбург, Россия, ул. Карла Маркса, д. 22 А
}

\begin{abstract}
Цель работы - изучение влияния сочетанной трансплантации мультипотентных мезенхимальных стромальных и гемопоэтических стволовых клеток на регенерацию печени в физиологических условиях и в условиях токсического гепатита. Методика. Эксперименты выполнены на 84 белых лабораторных мышах-самцах, возраст 7-8 мес. Токсический гепатит вызывали внутрибрюшинным введением четыреххлористого углерода $\left(\mathrm{CCl}_{4}\right.$ в дозе 50 мкг/кг. Животным опытной группы в хвостовую вену вводили мультипотентные мезенхимальные стромальные (ММСК, 4 млн клеток/кг) и гемопоэтические стволовые клетки (ГСК, 330 тыс. клеток/кг). Для инъекции полученные клетки суспендировали в 0,2 мл 0,9% раствора NaCl. Животным контрольной группы внутривенно вводили 0,2 мл 0,9 \% раствора $\mathrm{NaCl}$. Внутривенные введения осуществляли через 1 ч после введения четыреххлористого углерода однократно. Для трансплантации использовали ММСК третьего пассажа, а ГСК не подвергались культивированию. Изучали влияние сочетанной трансплантации ММСК и ГСК на биохимические показатели периферической крови и морфометрические показатели печени в физиологических условиях и после введения $\mathrm{CCl}_{4}$ на 1-е, 3-и, 7-е сут. Результаты. Показано, что проведение сочетанной трансплантации мультипотентных мезенхимальных стромальных и гемопоэтических стволовых клеток при токсическом гепатите приводило к снижению активности ферментов цитолиза, активации белоксинтезирующей функции печени. Также отмечалось увеличение количества гепатоцитов, повышение митотической активности, что указывает на активацию внутриклеточной регенерации. Обнаруженное увеличение числа двуядерных гепатоцитов, размеров ядра, ядерно-цитоплазматического соотношения говорит об усилении процесса внутриклеточной регенерации в печени.
\end{abstract}

Ключевые слова: токсический гепатит; регенерация печени; мультипотентные мезенхимальные стромальные клетки; гемопоэтические стволовые клетки.

Для цитирования: Маклакова И.Ю., Гребнев Д.Ю. Коррекция морфофункционального состояния печени при остром гепатите с помощью стволовых клеток. Патологическая физиология и экспериментальная терапия. 2020; 64(2): 46-53. DOI: 10.25557/0031-2991.2020.02.46-53

\author{
Для корреспонденции: Маклакова Ирина Юрьевна, e-mail: makliu@mail.ru \\ Финансирование. Исследование не имело спонсорской поддержки. \\ Конфликт интересов. Авторы заявляют об отсутствии конфликта интересов. \\ Участие авторов: концепция и дизайн исследования, сбор и обработка материала, написание текста - Маклакова И.Ю.; \\ концепция и дизайн исследования, написание текста, редактирование - Гребнев Д.Ю. \\ Поступила 17.12.2019 \\ Принята к печати 20.04.2020 \\ Опубликована 28.05.2020 \\ Maklakova I.Yu. ${ }^{1,2}$, Grebnev D.Yu. ${ }^{1,2}$

\section{Correction of the the liver morpho-functional state with stem cells in acute hepatitis} \\ 'Ural State Medical University, \\ Repina Str. 3, Ekaterinburg 620028, Russia; \\ ${ }^{2}$ Institute of Medical Cell Technologies, \\ Karla Marksa St. 22 A, Ekaterinburg 620026, Russia
}

The aim of the work was studying the effect of combined transplantation of multipotent mesenchymal stromal and hematopoietic stem cells on regeneration of the liver under the physiological conditions and in toxic hepatitis. Methods. Experiments were performed on 84 white laboratory male mice aged 7-8 months. Toxic hepatitis was induced by administration of carbon tetrachloride $(\mathrm{CCl} 4)$ at a dose of $50 \mu \mathrm{g} / \mathrm{kg}$, i.p. Mice were divided into experimental and control groups. The experimental group received caudal vein injections of multipotent mesenchymal stromal (MMSC) and hematopoietic stem cells (HSC) derived from the placenta chorion of female mice at respective doses of $4 \mathrm{M}$ cells $/ \mathrm{kg}$ and $330 \mathrm{~K}$ cells $/ \mathrm{kg}$ suspended in $0.2 \mathrm{ml}$ of $0.9 \% \mathrm{NaCl}$. Control animals 
were given $0.2 \mathrm{ml}$ of $0.9 \% \mathrm{NaCl}$, i.v. Intravenous injections were performed once 1 hour following the administration of carbon tetrachloride. MMSCs of the third passage were used for transplantation, while transplanted HSCs were not cultured. Effects of the combined MMSC and HSC transplantation on blood biochemistry and liver morphometry were studied under the physiological conditions and at 1,3, and 7 days after administration of CCI4. Results. In toxic hepatitis, the combined transplantation of multipotent mesenchymal stromal and hematopoietic stem cells resulted in decreased activity of cytolytic enzymes, activation of hepatic protein synthesis, increased number of hepatocytes, and increased mitotic activity indicative of activation of intracellular regeneration. Increases in the number of binuclear hepatocytes, nucleus size, and the nuclear-cytoplasmic ratio suggested an enhancement of intracellular regeneration in the liver.

Keywords: toxic hepatitis; liver regeneration; multipotent mesenchymal stromal cells; hematopoietic stem cells.

For citation: Maklakova I.Yu., Grebnev D.Yu. Correction of the the liver morpho-functional state with stem cells in acute hepatitis. Patologicheskaya Fizioilogiya i Eksperimentalnaya terapiya. (Patological Physiology and Experimental Therapy, Russian Journal). 2020; 64(2): 46-53. (in Russian).

DOI: $10.25557 / 0031-2991.2020 .02 .46-53$

For correspondence: Maklakova Irina Yurevna, associate Professor of pathological physiology of the USMU is conducted by the Ministry of health of Russia, senior researcher «Institute of medical cell technologies», laboratory of anti-aging technology, e-mail: makliu@mail.ru Acknowledgments. The study had no sponsorship.

Conflict of interest. The authors declare no conflict of interest.

Contribution: the concept and design of the study, collection and processing of material, writing a text — Maklakova I.Yu. ; the concept and design of the study, writing a text, editing - Grebnev D.Yu.

Information about the authors:

Grebnev D.Yu., https://orcid.org/0000-0002-5698-8404

Received 17.12.2019

Accepted 20.04.2020

Published 28.05.2020

\section{Введение}

Печень представляет собой важнейший орган, обеспечивающий постоянство внутренней среды организма. Воздействие гепатотропных ядов вызывает разрушение гепатоцитов с последующим развитием печеночной недостаточности. Ежегодно от печеночной недостаточности на Земле погибает около 2 млн человек. Летальность при печеночной недостаточности достигает $80 \%$, а в случае развития печеночной комы 80-90\% [1]. Это свидетельствует о том, что существующие на сегодняшний день терапевтические подходы к лечению печеночной недостаточности не эффективны, что диктует необходимость поиска новых методов лечения токсического гепатита. Обращает на себя внимание рост в последние годы количества публикаций, связанных с использованием биомедицинских клеточных продуктов. Так, в ряде работ показана эффективность использования мультипатентных мезенхимальных стромальных клеток (ММСК) с целью восстановления биохимических параметров периферической крови при токсическом гепатите [2, 3]. Появились работы об участии ММСК и ГСК в активации репаративных процессов в органах при различных видах повреждения (токсическом, облучении, травме) [4-6]. Учитывая биологические свойства мультипотентных мезенхимальных стромальных и гемопоэтических ство- ловых клеток, представляется перспективным использование сочетанной трансплантации этих видов клеток для активации регенерации печени при токсическом повреждении [7,8]. В последние годы в зарубежной и отечественной литературе увеличивается количество публикаций, свидетельствующих о вовлеченности в репаративную регенерацию печени ГСК и ММСК при ее токсическом повреждении $[9,10]$. Известно, что ММСК обладают способностью к миграции в ткани, подвергшиеся наибольшему повреждению, выработки противовоспалительных цитокинов (TGF- $\beta$, ИЛ-10) и факторов роста (SCF-stem cell factor, HGF-hepatocyte grow factor) [2, 9]. Также ММСК синтезируют хемоаттрактант для ГСК (SDF-1- stromal cellderived factor-1), который приводит к усилению хоуминга аллогенных и аутологичных ГСК в поврежденную печень [11-13]. ММСК и ГСК способны активировать регенерацию гепатоцитов, сливаясь с гепатоцитами - fusion-effect [14-16]. Источниками ГСК являются костный мозг, периферическая кровь, фетальные ткани. Установлено, что ткань зрелой плаценты содержит большее количество ГСК по сравнению с костным мозгом [17]. Также доказано, что плацентарные стволовые клетки обладают большим пролиферативным потенциалом, способностью к дифферен- 
цировке, синтезу биологически активных веществ, обладают более выраженной иммуномодулирующей активностью $[9,17]$. Кроме того, большим преимуществом является возможность получения клеток плаценты неоперативным путем.

Цель исследования - изучение процесса регенерации печени в условиях токсического гепатита на фоне сочетанной трансплантации мультипотентных мезенхимальных стромальных клеток и гемопоэтических стволовых клеток.

\section{Методика}

Эксперименты выполнены на 84 белых лабораторных беспородных мышах-самцах из питомника «White river» г. Уфа. Возраст животных 7-8 мес, масса 25-27 г. Все эксперименты, уход и содержание осуществлялись в соответствии с Директивой № 63 от 22 сентября 2010 г. Президиума и Парламента Европы «О защите животных, используемых для научных исследований» и приказом Минздрава РФ № 267 от 19.06.2003 «Об утверждении правил лабораторной практики». Протокол исследований одобрен локальным этическим комитетом ФГБОУ ВО «Уральский государственный медицинский университет» протокол № 8 от 20.10.2017. Токсический гепатит воспроизводили внутрибрюшинным введением четыреххлористого углерода $\left(\mathrm{CCl}_{4}\right)(50$ мкг/кг). Животным экспериментальной группы внутривенно вводили суспендированные в 0,2 мл $0,9 \%$ раствора $\mathrm{NaCl}$ ММСК и ГСК соответственно в дозе 4 млн клеток/кг и 330 тыс. клеток/кг. Животным контрольной группы в хвостовую вену вводили 0,2 мл $0,9 \%$ раствора $\mathrm{NaCl}$. Инъекции осуществляли через 1 ч после введения $\mathrm{CCl}_{4}$. Исследовали влияние сочетанной трансплантации ММСК и ГСК на биохимические показатели периферической крови и морфометрические параметры печени в физиологических условиях и после введения $\mathrm{CCl}_{4}$ на 1-е, 3-и, 7-е сут. Из опыта животных выводили декапитацией под легким эфирным наркозом.

Культуры ММСК и ГСК получали из хориона плаценты 5-ти мышей-самок (возраст 3-4 мес, срок гестации 18 сут). В исследовании использовано 32 плаценты. Мононуклеарную фракцию клеток получали последовательной механической и ферментативной (раствор аккутазы (Millipore, США)) обработкой ткани плаценты. Выделение ГСК осуществляли методом позитивной иммуномагнитной сепарации по антигенам SCA-1 (StemCell Technologies, CША) и CD 117 (StemCell Technologies, США) (X. Munira и соавт., 2009). Трансплантированные ГСК не подвергались культивированию.

Культивирование ММСК проводили в условиях $\mathrm{CO}_{2}$ - инкубатора (Termo Scientific, США) при температуре $37^{\circ} \mathrm{C}$ с содержанием углекислого газа $5 \%$ и влажностью 90\%. Состав среды культивирования: MesenCult MSC Basal Medium Mouse («StemCell Technologies», Канада) и MesenCult ${ }^{\mathrm{TM}}$ Proliferation Supplements Mouse («StemCell Technologies», Канада) в соотношении 4:1. Также в состав данной среды входило 2 ммоль раствора L-глутамина («StemCell Technologies», Канада) и антибиотики - пенициллин (50 ед/мл) и стрептомицин (50 мкг/мл) «StemCell Technologies», Канада. При формировании монослоя осуществляли пересев клеток. Для этого после удаления специализированной среды для культивирования к клеткам добавляли раствор аккутазы (StemCell Technologies, США), позволяющий разрушать межклеточные контакты и отделять клетки от дна чашки Петри, не нарушая при этом целостность мембраны клетки. Для нейтрализации фермента добавляли эквивалентный объем среды DMEM («StemCell Technologies», Канада), содержащей $10 \%$ по объему фетальной бычьей сыворотки (FBS, fetal bovine serum) («StemCell Technologies», Канада). В дальнейшем, клетки были суспендированы в специализированной среде для культивирования ММСК и подсчитаны в камере Горяева. Минимальное количество клеток, снимаемых после нулевого пассажа $-1,0$ х $10^{4}$ клеток/ $\mathrm{cm}^{2}$. Для трансплантации лабораторным животным были использованы ММСК третьего пассажа. Иммунофенотип MMCK характеризуется: CD105+, Sca1+, CD29+, CD45- [2]. Иммунофенотипирование суспензии ММСK проводили методом проточной цитометрии с использованием моноклональных антител, конъюгированных с флуорохромами (Becton Dickinson, США). В фракции трансплантируемых клеток оценивали содержание MMCK с иммунофенотипом положительных по CD105, CD29, Sca-1 и отрицательных по CD45 на проточном цитометре Beckman Coulter Navios с помощью набора Mouse Mesenchymal Stem CellMulti-Color Flow Cytometry Kit (Bio-Techne, США). Количество жизнеспособных клеток с фенотипом CD45-CD105+Sca1+CD29+ coставляло 93,5\% (рис. 1).

Иммунофенотип ГСК мыши характеризуется: Sca1+, CD38+, CD117+, Lin-, CD34-. Идентификацию ГСК проводили на проточном цитометре Beckman Coulter Navios. В суспензии трансплантируемых клеток оценивали содержание ГСК с иммунофенотипом положительных по CD117, Sca-1 и отрицательных по Lin- (CD45, C3e, Ly-6G, M1/70, Ter-119). Содержание жизнеспособных клеток после иммуномагнитной сепарации с иммунофенотипом CD117+, Sca-1+, Linсоставляло 90-96\% (рис. 2).

Гистологические срезы печени 3-5 мкм, окрашивали гематоксилином-эозином. Для морфометриче- 
ского анализа данных использовали компьютерную программу анализа изображений (Biovision, Россия). С этой целью производили микрофотосъемку случайных полей зрения гистологических препаратов циф- ровой камерой OLYMPUS XC30 на базе микроскопа OLYMPUS BX51 (OLYMPUS, Япония) при увеличении $\times 100, \times 200, \times 400, \times 600, \times 1000$ (не менее 10 полей зрения в каждом гистологическом срезе).

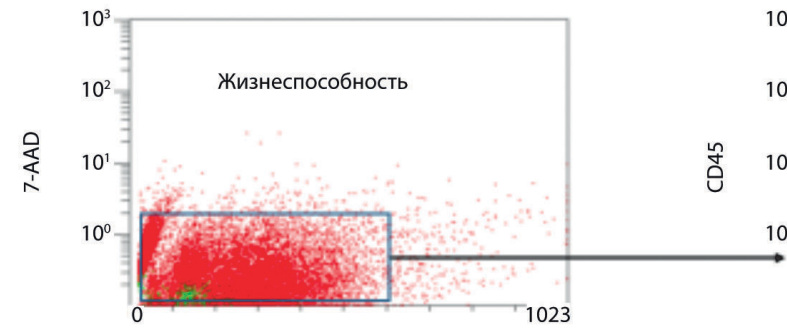

FS INT LIN

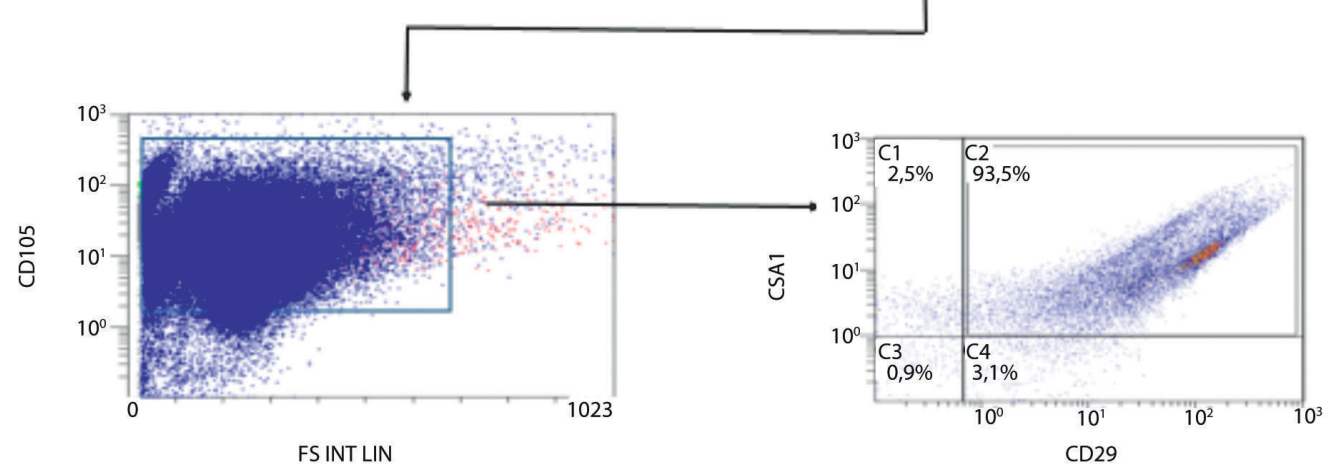

Рис. 1. Идентификация ММСК методом проточной цитофлуорометрии.

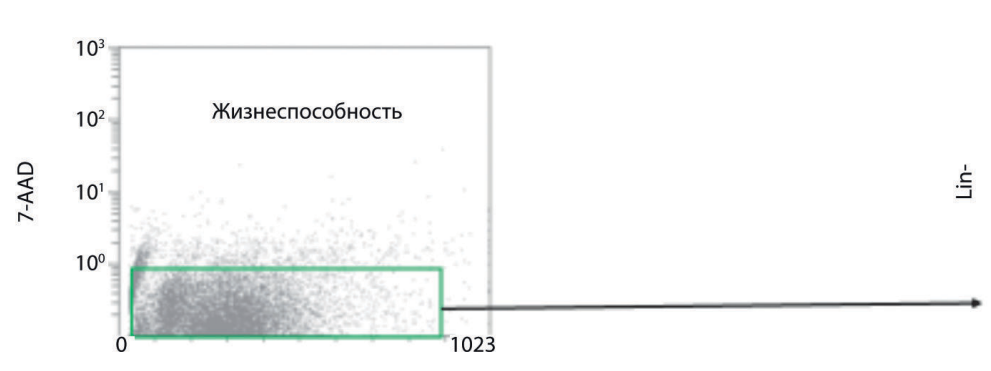

FS INT LIN

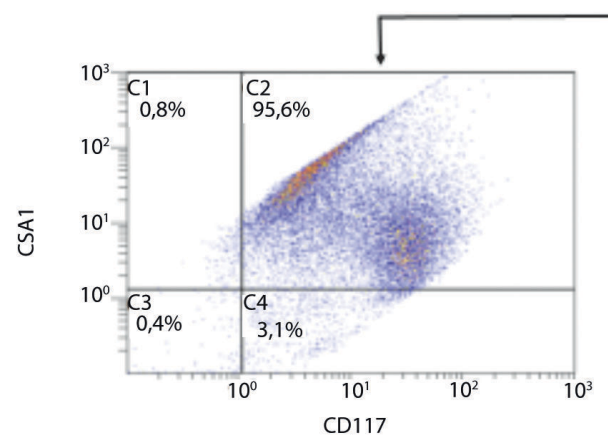

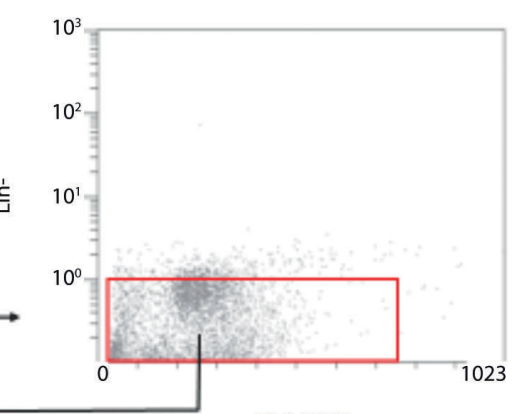

FS INT LIN

Рис. 2. Идентификация ГСК методом проточной цитофлуорометрии. 
Производили оценку следующих морфометрических показателей: количество гепатоцитов на 1 мм², площадь гепатоцитов, среднюю площадь ядра гепатоцита, площадь цитоплазмы гепатоцита, ядерно-цитоплазматический индекс (ЯЦИ), количество двуядерных гепатоцитов на 1 мм²$^{2}$ митотический индекс (МИ), апоптотический индекс (АИ). Ядерно-цитоплазматический индекс (ЯЦИ) определяли, как отношение площади ядра и цитоплазмы клетки. Митотический, апоптотический индексы выражали в промилле (\%o). Митотический индекс определяли, как отношение числа клеток в состоянии митоза к общему числу подсчитанных гепатоцитов. Верификация выраженности апоптоза осуществлялась с использованием метода ApopTag ${ }^{\circledR}$ Peroxidase In Situ Oligo Ligation (ISOL) (Millipore, США). Апоптотический индекс определялся как отношение числа клеток в состоянии апоптоза к общему числу подсчитанных гепатоцитов.

Оценку биохимических показателей периферической крови производили на автоматическом биохимическом анализаторе Chem Well 2910 (Combi). Изучали следующие биохимические показатели: уровень обще- го белка, альбумина, мочевины, глюкозы, общего билирубина, активность аспартатаминотрансферазы (АСТ), аланинаминотрансферазы (АЛТ), щелочной фосфатазы (ЩФ). При определении биохимических показателей использовали наборы компании «Ольвекс Диагностикум», Россия. Определение концентрации фибриногена проводили на анализаторе показателей гемостаза АПГ2-02-П с помощью набора ТехФибриноген тест (Технология Стандарт, Россия).

Статистическая обработка данных проведена с помощью программного пакета SPSS Statistics (версия $17,0)$. Значимость различий в сравниваемых выборках рассчитывали с применением непараметрического (рангового) метода Манна-Уитни.

\section{Результаты}

Сочетанная трансплантация ММСК и ГСК лабораторным животным без токсического гепатита (физиологические условия) не сопровождалось статистически значимыми изменениями биохимических показателей периферической крови и морфометрических параметров печени.

Таблица 1

Биохимические показатели крови при $\mathrm{CCl}_{4}$-гепатите на фоне сочетанного введения мультипатентных мезенхимальных стромальных клеток и гемопоэтических стволовых клеток

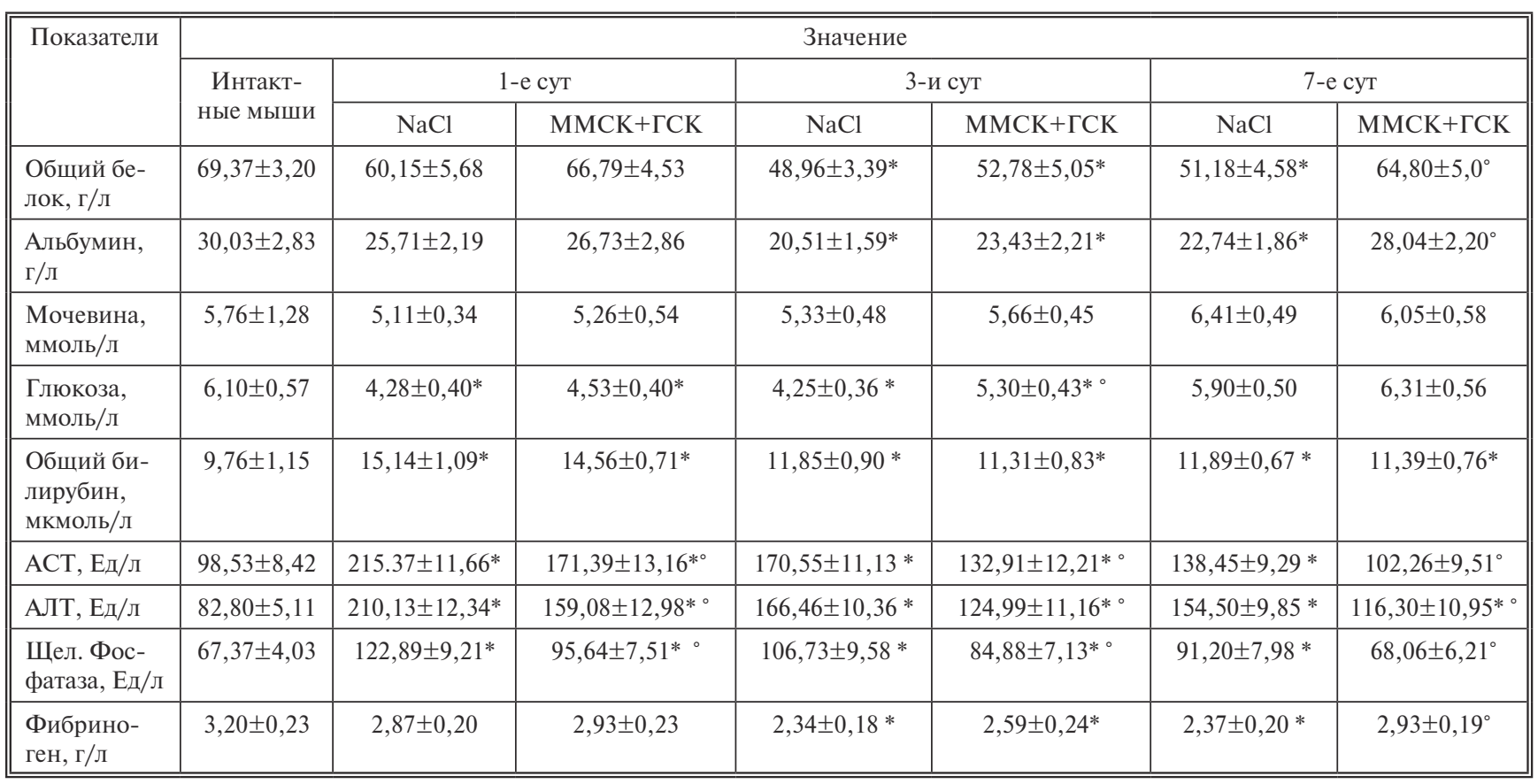

Примечание. Статистически значимые различия: * $p<0,05-$ с показателями интактной группы; ${ }^{\circ} p<0,05$ с показателями контрольной группы. 
При изучении биохимических показателей крови на 1-е сут после введения $\mathrm{CCl}_{4}$ на фоне сочетанной трансплантации ММСК и ГСК обнаружено снижение активности АСТ, АЛТ, щелочной фосфатазы. На 3-и сут отмечено снижение активности ферментов цитолиза гепатоцитов: АСТ, АЛТ, щелочной фосфатазы, а также повышение уровня глюкозы по сравнению с данными контроля. При анализе биохимических показателей на 7-е сут после введения $\mathrm{CCl}_{4}$ на фоне сочетанной трансплантации ММСК и ГСК отмечено снижение активности АСТ, АЛТ, щелочной фосфатазы. Также на фоне введения ММСК обнаружено повышение уровня фибриногена, общего белка, альбуминов, что говорит о восстановлении белоксинтетической функции печени (табл. 1).

На 1-е сут после введения $\mathrm{CCl}_{4}$ на фоне сочетанной трансплантации ММСК и ГСК обнаружено увеличение количества двуядерных гепатоцитов и повышение митотического индекса по сравнению с данными контрольной подгруппы. Как показали результаты иссле- дований начиная с 3-х сут проявляется отчетливое влияние сочетанного введения ММСК и ГСК на процессы регенерации: статистически значимо увеличивалось количество гепатоцитов на 1 мм², средняя площадь ядер гепатоцитов, ядерно-цитоплазматический индекс, количество двуядерных гепатоцитов, митотический индекс по сравнению с контролем. Такая же динамика прослеживается и на 7-е сут. Положительный эффект сочетанного введения ММСК и ГСК подтверждается также снижением в динамике величины апоптотического индекса (табл. 2).

\section{Обсуждение}

Полученные данные свидетельствуют о способности сочетанной трансплантации ММСК и ГСК увеличивать количество гепатоцитов, о чем свидетельствует активация митотической активности и ингибирование запрограммированной клеточной гибели. Повышение митотической активности гепатоцитов, можно объяснить способностью ММСК к выработке гепато-

Таблица 2

Морфометрические параметры при $\mathrm{CCl}_{4}$ - гепатите на фоне сочетанного введения мультипатентных мезенхимальных стромальных клеток и гемопоэтических стволовых клеток

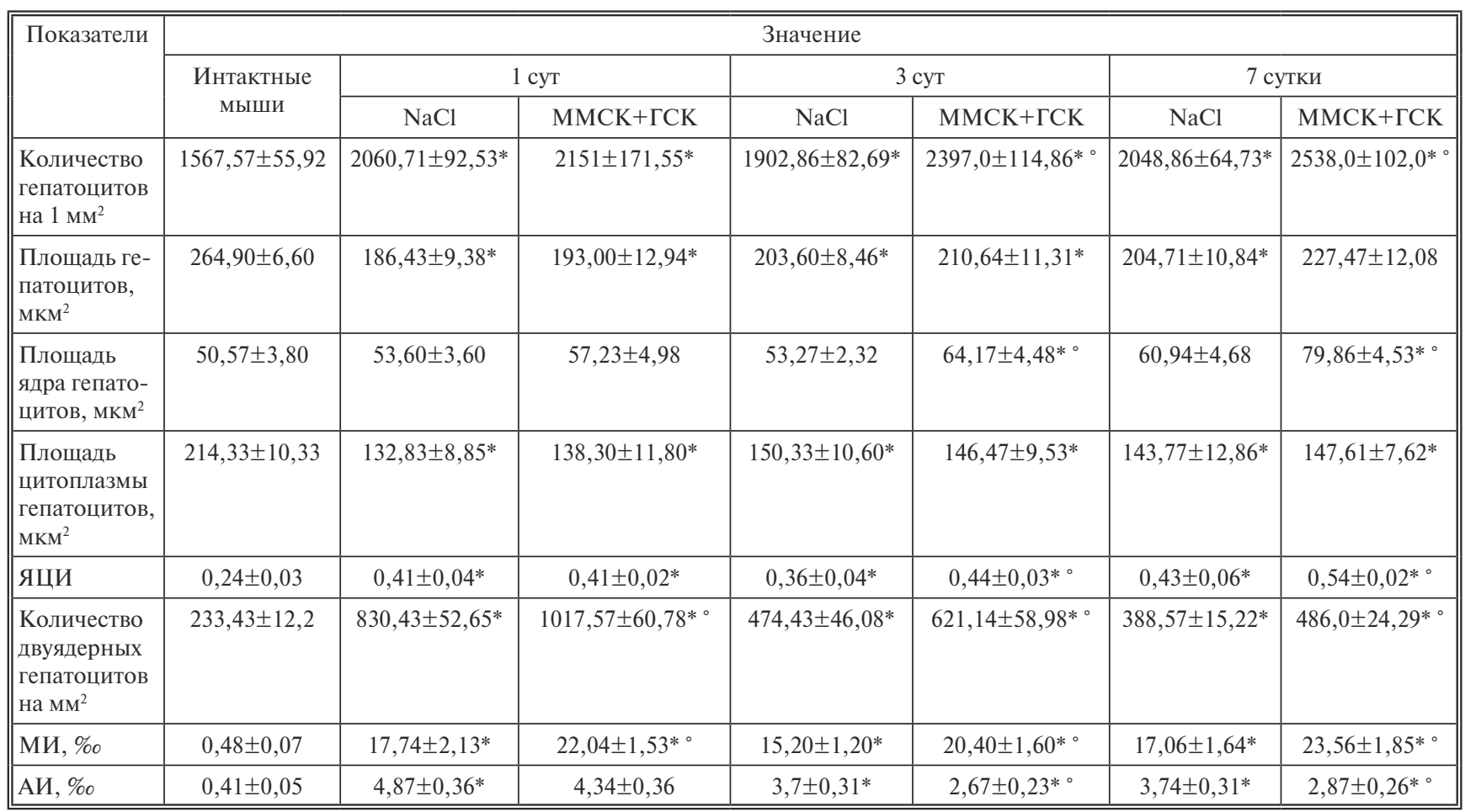

Примечание. Статистически значимые различия: * $p<0,05-$ с показателями интактной группы; ${ }^{\circ}<0,05$ с показателями контрольной группы. 
цитарного фактора роста - фактора стволовой клетки. Увеличение размеров ядра, количества двуядерных клеток свидетельствуют об активации процессов внутриклеточной регенерации. Эти изменения можно объяснить слиянием трансплантированных и аутологичных ГСК с гепатоцитами. При анализе данных периферической крови выявлено снижение активности АЛТ, АСТ, щелочной фосфатазы. Снижение активности ферментов цитолиза определяется способностью ММСК через формирование межклеточных контактов индуцировать в клетках образование белков теплового шока (70 кД). Белки теплового шока с данной молекулярной массой, стабилизируя цитоскелет клетки, увеличивают их устойчивость к повреждению. В настоящем исследовании также показано, что сочетанная трансплантация ММСК и ГСК обеспечивает активацию белоксинтетической функции печени. Таким образом, результаты исследования продемонстрировали способность сочетанной трансплантации ММСК и ГСК активировать процессы регенерации печени в условиях ее токсического повреждения.

В современной литературе широко обсуждаются эффекты использования фармацевтических средств при токсическом гепатите. Сюда можно отнести препараты природного происхождения на основе фосфолипидов и триацилглицеринов и другие соединения, нормализующие метаболические процессы в печени и восстанавливающие целостность мембран гепатоцитов [18-20]. Однако трансплантируемые ММСК и ГСК имеют более разнообразные механизмы действия (противовоспалительное действие, ингибирование запрограммированной клеточной гибели, активация митотической активности). Это делает перспективным дальнейшее изучение влияния стволовых клеток на структуру и функцию печени в условиях ее токсического повреждения.

\section{Литература \\ (п.п. 2-4; 7-9; 12-20 см. References)}

1. Российский статистический ежегодник. 2018: Стат. сб./Росстат. P 76 М., 2018.

5. Дешевой Ю.Б, Мороз Б.Б., Насонова Т.А., Лебедев В.Г., Добрынина О.А., Лырщикова А.В. Влияние мультипатентных мезенхимальных стромальных клеток жировой ткани на восстановление кожи при местных лучевых поражениях. Патологическая физиология и экспериментальная терапия. 2017; 61(4): 62-6. https://doi.org/10.25557/IGPP.2017.4.8524

6. Богданенко Е.В., Сергиевич Л.А., Карнаухов А.В., Карнаухова Н.А., Лизунова И.А., Карнаухов В.Н. Изучение регенеративного потенциала стволовых клеток костного мозга для лечения механических травм кожи в модельных экспериментах на мы- шах. Патологическая физиология и экспериментальная терапия. 2020; 64(1): 31-8.

DOI: $10.25557 / 0031-2991.2020 .01 .31-38$

10. Онищенко Н.А., Люндуп А.В., Газизов И.М. и др. Двухфазная динамика воздействия мезенхимальных мультипотентных стромальных клеток (ММСК) костного мозга на печень при моделировании фиброзирующего гепатита. Вестник трансплантологии и искусственных органов. 2011; том XIII(3): 51-8.

11. Маклакова И.Ю., Гребнев Д.Ю., Ястребов А.П. Влияние экстремальных факторов на хоуминг мультипотентных мезенхимальных стромальных клеток. Патологическая физиология и экспериментальная терапия. 2015; 59(4): 82-6.

\section{References}

1. Russian statistical yearbook. [Rossiyskiy statisticheskiy ezhegodnik]. Stat. sb./Rosstat, P 76. Moscow: 2018. (in Russian)

2. Prockop D.J., Oh J.Y Mesenchymal stem/stromal cells (MSCs): role as guardians of inflammation. Mol. Ther. 2012; 20(1): 14-20.

3. Maria P. de Miguel, I. Prieto, A. Moratilla, J. Arias, M. A. Aller. Mesenchymal Stem Cells for Liver Regeneration in Liver Failure: From Experimental Models to Clinical Trials. Hindawi Stem Cells International Volume 2019, Article ID 3945672, P. - 12.

https://doi.org/10.1155/2019/3945672

4. Danilova I, Medvedeva S, Bulavintseva T, Mukhlynina E. The role of stem cell factor in the regeneration after toxic Liver injury World Congress on Hepatitis. J Liver. 2015; Volume 4, Issue 3.

5. Deshevoy Yu.B., Moroz B.B., Nasonova T.A., Lebedev V.G., Dobrynina O.A., Lirhshikova A.V. Effect of cultivated multipotent mesenchymal stromal cells of adipose tissue to restore skin with local radiation lesions. Patologicheskaya Fiziologiya i Eksperimentalnaya terapiya. 2017; 61(4): 62-6. https://doi.org/10.25557/IGPP.2017.4.8524. (in Russian)

6. Bogdanenko E.V., Sergievich L.A., Karnaukhov A.V., Karnaukhova N.A., Lizunova L.A., Karnaukhov V.N. The regenerative potential of stem cells from the whole bone marrow for the treatment of skin mechanical trauma in a murine model. Patologicheskaya Fiziologiya i Eksperimental'naya terapiya. 2020; 64(1): 31-8. DOI: 10.25557/00312991.2020.01.31-38. (in Russian)

7. Thawley V. Acute Liver Injury and Failure Veterinary Clinics of North America: Small Animal Practice. May 2017; 47(3): 617-30.

8. Michalopoulos G.K. Liver regeneration. J. Cell Physiol. 2007; 213(2): 286-300.

9. Jung J., Choi J., Lee Y., Park J., Il-Hoan Oh, Seong-Gyu et al. Human placenta-derived mesenchymal stem cells promote hepatic regeneration in CCl4-Injured rat liver model via increased autophagic mechanism. STEM CELLS. 2013; 31: 1584-96.

10. Onishchenko N.A., Lyundup A.V., Gazizov I.M. Two-phase dynamics of the impact of mesenchymal multipotent stromal cells (MMSCs) of bone marrow on the liver in the simulation of fibrosing hepatitis. Vestnik transplantologii i iskusstvennykh organov. 2011, Vol. XIII(3): 51-8. (in Russian)

11. Maklakova I.Yu., Grebnev D.Yu., Yastrebov A.P. Influence of extreme factors on the homing of multipotent mesenchymal stromal cells Patologicheskaya fiziologiya i eksperimental'naya terapiya. 2015; 59(4): 82-6. (in Russian)

12. Maklakova I.Y., Grebnev D.Y. Effects of combined transplantation of multipotent mesenchymal stromal and hemopoietic stem cell on regeneration of the hemopoietic tissue. Bulletin of Experimental Biology and Medicine. 2017; 163(1): 61-4. 
13. Brilliant A.A., Brilliant Yu.M., Sazonov S.V. Characteristics of the relation between epitheliai-mesenchymal transition and proliferative activity in breast carcinomas. European Journal of Cancer. 2013; 49( S2): 216.

14. Samsonraj, R.M., Raghunath, M., Nurcombe, V., et al., Concise review: multifaceted characterization of human mesenchymal stem cells for use in regenerative medicine. Stem Cells Transl. Med. 2017; 6(12): 2173.

15. Marfy-Smith SJ, Clarkin CE. Are mesenchymal stem cells so bloody great after all? Stem Cells Translational Medicine. 2017; 6: 3-6.

16. Pilat N., Unger L., Berlakovich G. A. Implication for Bone Marrow Derived Stem Cells in Hepatocyte Regeneration after Orthotopic Liver Transplantation/ Hindawi Publishing Corporation. International Journal of Hepatology. Vol. 2013, Article ID 310612, P. 7 http:/ /dx.doi.org/10.1155/2013/310612
17. Jason A. Meierhenry, Volodymyr Ryzhuk, Maricel G et al. Placenta as a Source of Stem Cells for Regenerative Medicine. Curr Pathobiol Rep. 2015; 3: 9-16.

DOI 10.1007/s40139-015-0070-6

18 Guo, Q., Zhang Q.-Q., Chen J., Xu F.-G. Liver metabolomics study reveals protective function of Phyllanthus urinaria against $\mathrm{CCl}$-induced liver injury. Chinese journal of natural medicines. 2017; 15(7): 525-33.

19. Kuriakose, J., Lal H.R., Vysakh A., Eldhose B., Latha M.S. Terminalia bellirica (Gaertn.) Roxb. fruit mitigates $\mathrm{CCl} 4$ induced oxidative stress and hepatotoxicity in rats. Biomedicine and pharmacotherapy. 2017; 93: 327-33.

20. Mbarki, S., Alimi H., Bouzenna H., Elfeki A., Hfaiedh N. Phytochemical study and protective effect of Trigonella foenum graecum (Fenugreek seeds) against carbon tetrachloride-induced toxicity in liver and kidney of male rat. Biomedicine and pharmacotherapy, 2017; 88: 19-26.

\section{Сведения об авторах:}

Маклакова Ирина Юрьевна, канд. мед. наук, ассистент каф. патологической физиологии ФГБОУ ВО УГМУ Минздрава России; ст. науч. сотр. ГАУЗ СО «Институт медицинских клеточных технологий; e-mail: makliu@mail.ru;

Гребнев Дмитрий Юрьевич, зав. каф. патологической физиологии ФГБОУ ВО УГМУ Минздрава России, доктор мед. наук, ст. науч. сотр. ГАУЗ СО «Институт медицинских клеточных технологий»; e-mail: dr-grebnev77@mail.ru 